\title{
Rune Ervik and Tord Skogedal Lindén (eds.) (2013). The Making of Ageing Policy: Theory and Practice in Europe. Cheltenham, UK: Edward Elgar, 304 pp. ISBN 9781781952474 (hardback)
}

\section{REVIEWEd by Marvin Formosa*}

The second half of the 20th century witnessed unprecedented demographic changes. Declining fertility rates and mortality levels, and major improvements of life expectancies at birth, had far-reaching effects on global population trends to the extent that the present epoch has been referred to as the "age of ageing" (Magnus 2008). As a result, it is not surprising that in recent years ageing policy has emerged at the forefront of social policies in many countries all over the globe. Indeed, various government statements highlight and refer to the problem of the ageing workforce, the problem of economic sustainability in long-term care, the problem of the lack of social participation on behalf of older persons, the problem in ensuring sustainable pensions for all, amongst others.

In forums, policy makers are quick to emphasise how global, regional and national strategies are hinged on an altruistic belief that no stone should be left unturned so that older persons are enabled to experience active, successful and productive lifestyles. Nevertheless, critical gerontology documents clearly show that demographic trends are secondary influences

* Marvin Formosa, Gerontology Unit, Faculty for Social Wellbeing, University of Malta, Msida, Malta 
International Journal of Ageing and Later Life

to the nature of the debate. As Walker and Phillipson (1986: 1) underlined so many years ago, "the major determinant [for social policy on ageing] is ideology." This collection of chapters is precisely a move in such an intellectual tradition, seeking to illustrate the ideological and institutional factors that underlie policy decisions relating to ageing in different European countries.

The Making of Ageing Policy demonstrates, as illustrated in Sara Arber's blurb on the book back cover, "the pivotal role of ideas and international organizations in shaping the policy and practice landscape" of welfare reforms for older persons in Europe. The book drives the point that seemingly neutral terms, such as active ageing, are ultimately grounded in an economistic rationale whose overriding raison d'être is to making people extend their working lives. Whilst there is nothing inherently wrong in such a policy direction, the fact that policy makers mask this ideological grounding in functionalist discourse of well-being should be a key point of deliberation in "critical" social policy analysis.

This collection of chapters emerged from an international workshop on "Ideas and practices of ageing policies: European and national perspectives" in Bergen, in March 2012, with most of the chapters the volume originating as presentations during such an event. It is welcome to note that contrary to most collections of edited books originating from workshop or seminar events, The Making of Ageing Policy includes a strong introductory chapter that puts forward the empirical and ideological context as a backdrop to the ensuing chapters. "Introducing ageing policy: Challenges, ideas and responses in Europe" provides a thorough assessment of the extent that a variety of paradigms unfold across various policy areas and national situations by outlining the demographic changes and challenges, whilst also operationalizing ageing policy.

The consequent ten chapters view critical and humanistic dimensions of ageing through various lens: the rhetoric, theory and practice of active ageing (Alan Walker and Liam Foster); ageing policy ideas in the field of health and long-term care (Nanna Kildal and Even Nilsson); policymaker's views on the inclusion of older people's interest organizations (Martha Doyle and Virpi Timonen); government policy recommendations on pension (Tord Skogedal Lindén); ageing policy in Germany (Christof Schiller), impact of the transition of market economy on ageing policy 
(Anna Ruzik-Sierdzińska, Jolanta Perek-Bialas and Konrad Turek); policy paradigms on active ageing in Britain and Norway (Rune Ervik and Ingrid Helgøy); aging and long-term care in Poland and Italy (Zuzanna Drożdżak and colleagues); and strategies to meet long-term care needs in Norway, the United Kingdom and Germany (Rune Ervik, Ingrid Helgøy and Tord Skogedal Lindén). All these chapters make a major contribution to providing insights into the value basis and justifications of ageing policies, the potential for conflict and how policy ideas are embedded in the advocacy for reform of ageing policy. Authors deliver detailed normative analysis of polices on active, productive and successful ageing, whilst also contributing to the changing landscape of ageing politics and policies throughout Europe.

The final chapter includes a fitting closure to the book by returning to some of the key topics raised in the introduction and preceding chapters. This chapter revisits the challenges of population ageing, pinpointing the role of politics and policies in determining the scope of these contests. It also addresses the political dimension and the ways in which policy makers overcome resistance and create consensus, as well as reflecting on the ambiguity of the notions of active and productive ageing policies in European policies. At the same time, the concluding chapter presents some findings from comparative studies in three main areas of the welfare state - namely, pension, labour market and long-term care. It ends by posing a number of questions that merit further analysis in future treatises on the subject, such as "Did the European Year for Active Ageing have a real influence, or was it just cheap talk?" and "How will the financial crisis contribute to making of ageing policy?" There is no doubt that one expects many ageing policy reforms to be open to the study of the interaction, ideas and institutions in the foreseeable future.

This compendium of articles will certainly provide insightful ideas to students, academics and researchers alike who deal with demographic challenges across a wide spectrum of policy sectors. It will also appeal to practitioners in social and health care professions with an interest in ageing studies. There is no doubt that this publication has much to offer to theorising and empirical understanding of what it means to grow old in contemporary societies. 
International Journal of Ageing and Later Life

\section{References}

Magnus, B. (2008). The Age of Ageing: How Demographics are Changing the Global Economy and Our World. Hoboken, NJ: Wiley.

Walker, A. \& Phillipson, C. (1986). Introduction. In A. Walker \& C. Phillipson (eds.), Ageing and Social Policy: A Critical Assessment (pp. 1-12). Gower, MO: Aldershot. 